\title{
LOS NUEVOS VOLUNTARIOS: NATURALEZA Y CONFIGURACIÓN DE SUS INICIATIVAS SOLIDARIAS
}

\author{
José Luis Izquieta Etulain y Javier Callejo González \\ Universidad de Valladolid \\ E-mail: izquieta@soc.uva.es
}

\begin{abstract}
RESUMEN
La expansión y el creciente protagonismo del voluntariado altruista, así como los escasos estudios empíricos sobre la conducta y las representaciones de estos actores, nos llevaron a estudiar los voluntarios de una organización representativa (Cruz Roja) con el objetivo de conocer las imágenes, expectativas y actitudes que les mueven y orientan. El trabajo se centra en tres aspectos. En primer lugar, se define y explica el contexto social en el que se sitúa el objeto de estudio, así como la perspectiva teórica desde la que se aborda. A continuación, se identifican y definen las imágenes, las representaciones que los voluntarios tienen de su compromiso, de las personas a las que atienden y de la actividad que realizan, proponiendo una tipología de los nuevos voluntarios. Finalmente, se realiza un análisis en el que, además de contrastar nuestro estudio con otras investigaciones y con los modelos de la acción colectiva, aportamos una interpretación de su naturaleza, significado y alcance social.
\end{abstract}

La presencia y el crecimiento durante las últimas décadas del asociacionismo «altruista» constituye un rasgo relevante de nuestra época. El prójimo, su sufrimiento, los problemas y las necesidades de distintos colectivos despiertan la sensibilidad de personas que se asocian voluntariamente o participan en organizaciones públicas con la intención de cooperar a la solución o disminución de esas situaciones sin buscar una contraprestación externa.

El origen de este tipo de iniciativas no es reciente ni exclusivo de nuestra sociedad. Los historiadores de la acción social confirman la presencia, desde 
antiguo, de asociaciones voluntarias dedicadas a tareas de beneficencia y filantropía con desvalidos y menesterosos. Su existencia actual presenta, no obstante, rasgos diferentes a los del pasado: se trata de asociaciones que surgen en el seno de una sociedad caracterizada, paradójicamente, por su talante individualista y por su tendencia a la privacidad; aparecen para resolver necesidades y problemas creados por la modernidad e insuficientemente cubiertos desde las organizaciones formales; crecen en el contexto del Estado de Bienestar para cubrir vacíos y demandas a los que no llega la protección pública; se desarrollan dentro de un espacio social y político en el que se experimentan los lastres de la democracia, sus carencias y excesos y en el que emerge con fuerza la Sociedad Civil; son el producto o la consecuencia de un conjunto de aspiraciones que tratan de paliar los crecientes desequilibrios y las profundas injusticias derivadas del sistema de valores imperantes en nuestra cultura (Ascoli, 1987; Casado, 1992; Giner y Sarasa, 1996; Rodríguez Cabrero, 1996).

Todos estos aspectos revelan la novedad de estas iniciativas solidarias, permitiendo, asimismo, entender su complejidad y ayudando a captar la pluralidad de enfoques y aspectos que pueden considerarse en su estudio. A pesar de ello, no son muchas las investigaciones que hasta el momento se han realizado en nuestro país sobre su naturaleza, expresión y dinámicas. Dichos estudios adolecen, además, de cierta parcialidad; se fijan en aspectos generales, resaltan los datos cuantitativos y dejan de lado la consideración de sus actores y representaciones.

Conscientes de estos vacíos y del resurgir del voluntariado, decidimos acometer una investigación empírica intentando penetrar en los rasgos que definen e identifican hoy a los nuevos voluntarios. Buscamos, fundamentalmente, conocer qué motivaciones provocan su decisión, cuáles son sus actitudes, qué imágenes y expectativas poseen. Pretendíamos, en definitiva, captar los referentes desde los que piensan y actúan estos agentes.

Para alcanzar este objetivo optamos por un modelo teórico y una perspectiva metodológica que tuviera en cuenta a los actores de estas organizaciones, su perspectiva y posición respecto al fenómeno que se analiza. En el presente trabajo mostramos algunos de los resultados y conclusiones de nuestra investigación. Tres son los aspectos en los que nos detendremos. En primer lugar, presentamos el contexto en el que se sitúa nuestro estudio. Para ello establecemos el tipo de voluntarios en los que nos fijamos y la perspectiva teórica desde la que abordamos su análisis. En segundo lugar, mostramos los valores y pautas que les identifican. Nos detenemos en la delimitación de sus motivaciones y en las imágenes que tienen de su cooperación, de las personas a las que ayudan y de la actividad que realizan. Delimitamos también las actitudes y los comportamientos que asumen en cada uno de estos frentes, tratando de precisar los distintos tipos de voluntarios que hoy se hacen presentes en nuestra sociedad. Finalmente, aportamos una interpretación de estas nuevas iniciativas. Desde los resultados obtenidos en nuestro estudio explicamos las causas de su creciente expansión, contrastamos nuestra visión con la que aportan otros estudiosos 
del voluntariado y delimitamos algunas de sus características y constantes más representativas.

Con todo ello, y apoyándonos en los resultados de nuestra investigación, pretendemos aportar una vía de análisis y un marco de interpretación que permitan avanzar en la comprensión de estas nuevas iniciativas solidarias ${ }^{1}$.

\section{LOS NUEVOS VOLUNTARIOS «ALTRUISTAS»: EXPRESIÓN SOCIAL Y HORIZONTES DE ESTUDIO}

El asociacionismo cívico y solidario se revela hoy como una de las formas de acción colectiva de mayor relieve y alcance. Se trata de un tipo de iniciativas que quedan lejos del asociacionismo clásico, ya sea político, económico o de clase.

Su expresión y proyección son, no obstante, complejas y dispares. Ello nos obliga a definir el contexto social en el que emergen, a establecer el marco teórico desde el que abordamos su análisis y a exponer la estrategia metodológica que guió nuestro estudio.

\subsection{LAS ASOCIACIONES VOLUNTARIAS: PROYECCIÓN Y DIMENSIONES ACTUALES DE LAS INICIATIVAS «ALTRUISTAS»}

La dinámica seguida por nuestra sociedad en las últimas décadas presenta rasgos contradictorios y paradójicos. Por un lado, se constata la presencia de un talante individualista, reflejo y expresión de una tendencia dominante en las sociedades modernas, en las que el afán de autonomía, el deseo de realización personal y la aspiración a disfrutar al máximo de la vida parecen inseparables de una sociedad que ha erigido al individuo libre como valor cardinal (Lipovetski, 1986; Béjar, 1988). Por otro lado, emerge con fuerza una disposición de apertura hacia lo social que conduce a distintas formas de acción colectiva, a la búsqueda de un modo de vida en el que «los otros», sus urgencias y problemas cobran un protagonismo especial. La tendencia al individualismo parece que no disuelve los vínculos sociales, sino que, por el contrario, el yo sin trabas, totalmente desarraigado, estaría dando paso a un yo saturado; a un yo necesitado de vínculos, de espacios de comunicación, afecto, encuentro y cooperación; a un yo «relacional» proyectado en redes sociales, grupos, asociaciones y comunidades (Geergen, 1992; Barcellona, 1992; Donati, 1997).

Este impulso puede explicar la vitalidad del asociacionismo voluntario.

Los límites de espacio y la existencia de un informe exhaustivo en el que se recogen los textos y la documentación de nuestras entrevistas nos lleva a prescindir en nuestra exposición de las citas textuales, en las que se explicitan los contenidos, expresiones y frases de nuestro análisis. El lector puede encontrar estos textos en Callejo e Izquieta (1996). 
Parece que la dinámica de nuestra sociedad, con sus déficits y límites, conduce a la aparición de demandas y valores, de nuevos movimientos e iniciativas sociales, que, al mismo tiempo que producen una reestructuración de la sociedad civil, impulsan la recuperación de actitudes y conductas altruistas y solidarias, virtudes cívicas que conectan con la expresión secular de la Fraternidad (Giner y Sarasa, 1996). Su expansión se presenta por ello como una constante de la sociedad moderna, una característica que aparece asociada a un determinado nivel de desarrollo económico, de modernización y de cambio social (Meister, 1974).

El crecimiento y configuración del asociacionismo voluntario presentan, sin embargo, notables diferencias entre unos países y otros. Algunos autores advierten y distinguen dos modelos (nórdico y mediterráneo) con características estructurales diferentes y en los que su trayectoria histórica y reciente revelan distintas tasas de afiliación (Meister, 1974).

Nuestro país ha sido considerado tradicionalmente dentro del tipo de sociedades con bajas tasas de afiliación (Sarasa, 1995). Este planteamiento reclama, no obstante, algunas precisiones. Los escasos estudios que se han realizado sobre el asociacionismo voluntario en España ponen de manifiesto la existencia de diferencias significativas entre las distintas regiones, así como porcentajes muy diversos de participación y afiliación según el tipo o clase de asociación (Prieto Lacaci, 1993; CECS, 1999). Por otro lado, la expansión de estas asociaciones ha sido constante desde los años setenta y ha tenido un crecimiento progresivo en los últimos veinticinco años. Ya a finales de los años sesenta, nuestro nivel asociativo era similar al de la Gran Bretaña y se hallaba por encima de países como Italia y México (FOESSA, 1966: 298). Al mismo tiempo, tal como advierten distintos estudios, entre 1965 y 1990 se crearon más de 150.000 asociaciones voluntarias, de las cuales el 85 por 100 son no lucrativas. Los datos del Registro Nacional de Asociaciones nos permiten observar la magnitud del crecimiento asociativo en nuestro país entre 1980 y 1990. Un indicador del dinamismo de este período es que durante el mismo se crearon cerca de 66.000 asociaciones voluntarias sin fines de lucro, pasándose de 47.464 a 113.095 asociaciones, lo que supuso un crecimiento del 238 por 100 (Prieto Lacaci, 1999: 27). La tasa de afiliación ha evolucionado, además, positivamente a lo largo de los últimos diez años, sobre todo desde 1985, y se sitúa actualmente en torno al 35 por 100 de la población mayor de 18 años (Prieto Lacaci, 1993: 197).

Los rasgos que presentan estas asociaciones voluntarias son plurales y heterogéneos. Se trata de asociaciones que actúan en diversos campos y con propósitos bien distintos. Difieren tanto en su naturaleza y tamaño como en su composición y en el modo en que se expresan y actúan (Casado, 1992). Desde una perspectiva amplia se las considera bajo el epígrafe equívoco del «Tercer Sector», incluyendo en él toda una serie de asociaciones y agrupaciones que tienen en común el carácter de la voluntariedad. Sin embargo, esta denominación es un tanto simplificadora y reduccionista, pues deja de lado la multiplicidad de 
matices que las distingue e identifica (Rodríguez Cabrero, 1996: 22-23). Se las considera, además, preferentemente como alternativa y vía de solución a los límites y deficiencias que presenta el Estado de Bienestar, y se las entiende como asociaciones o grupos de carácter privado, cuando es obvio que tienen una dimensión pública, al estar orientadas hacia los demás.

$\mathrm{Su}$ identificación y diferencias vienen determinadas, principalmente, por los objetivos o metas que persiguen. De acuerdo con este criterio, utilizado por el Registro Nacional de Asociaciones para agrupar a las asociaciones no lucrativas, se proponen hasta nueve categorías diferentes, que no siempre son las más adecuadas desde una perspectiva analítica. En esta clasificación aparecen mencionadas las asociaciones filantrópicas, dentro de las cuales se incluyen las asociaciones benéficas, asistenciales y de acción social, educativa, cultural y sanitaria. Se trata, por tanto, en este caso de un tipo de asociaciones orientadas hacia los demás y que persiguen la ayuda, el servicio, el cuidado y la protección de personas desfavorecidas.

Un matiz que permite precisar algo más la identidad de estas asociaciones es el modo en que sus miembros se plantean la participación y la acción voluntaria. Siguiendo este criterio constatamos la presencia de dos situaciones diferentes. Se observa la existencia de asociaciones constituidas por personas que persiguen objetivos comunes desde una iniciativa autónoma, sin buscar un beneficio material, pero vinculadas por su propio interés, cuyo objetivo o intención es mejorar sus condiciones de vida, ayudándose mutuamente (asociaciones de autoayuda). Junto a ellas existen asociaciones formadas por personas que disponen de recursos (bienes, tiempo...) y que se asocian para ofrecer ayuda y servicios a otras personas sin buscar una contraprestación económica o material directa. En este caso estamos ante asociaciones y voluntarios que al asociarse dan prioridad a los intereses ajenos, no buscan una contraprestación o una compensación visible y directa con su ayuda. Este tipo de asociaciones podríamos considerarlas propiamente como «altruistas».

Aunque el impulso de este compromiso «altruista» es desigual, parece que este tipo de asociaciones tiene un papel y un protagonismo crecientes. Cada vez es mayor el número de ciudadanos que realizan alguna actividad filantrópica (James, 1989). En nuestro país su expansión es constante desde la década de los ochenta. Tal como advierten algunos autores, aunque la intensidad y el ritmo de crecimiento de las distintas asociaciones han sido distintos, «el crecimiento más intenso en la última década corresponde a las asociaciones filantrópicas, que han aumentado sus efectivos el 447 por 100» (Prieto Lacaci, 1993: 204).

A efectos de análisis, parece que los requisitos o los rasgos que identifican a este tipo de conducta son su voluntariedad e intencionalidad, su pretensión de mejorar el bienestar de otro y el no esperar recompensas externas. Este tipo de conducta presenta dos rasgos representativos: 1) la proyección de actitudes de fraternidad, caridad o solidaridad directa sobre terceros, es decir, sobre seres humanos que no pertenecen a la misma familia, al grupo de amigos o compa- 
ñeros; 2) la integración de ese comportamiento en asociaciones o agrupaciones orientadas hacia su manifestación, canalización y logro de los efectos de ayuda deseados (Giner, 1995: 17)

Hay que advertir, no obstante, que al definir a estas asociaciones como «altruistas» aparece un problema de precisión y de cierta equivocidad. El término "altruismo» se asocia a otros sinónimos (compasión, caridad, solidaridad, dádiva). La comprensión y explicación del «altruismo» admiten, además, diferentes enfoques. Se trata de un término que se refiere a acciones gratuitas de múltiples variantes en las que se dan muchos matices. Junto a un «altruismo duro", que aparece en las relaciones familiares, se advierte la presencia de un «altruismo blando» que emerge en las relaciones de reciprocidad. La ambivalencia del don, la doble tensión del dar y recibir, recibir y devolver, el eje normativo que mueve a la reciprocidad nos descubre una forma de conducta en la que aparecen y se dan lógicas diferentes que se combinan y expresan de diferente modo (Izquieta, 1987).

Por otro lado, este tipo de conducta puede presentarse entremezclada y confundida con diversas intenciones o motivaciones. El deber, la obligación, el sentirse bien con uno mismo, la satisfacción que se experimenta como contrapartida de la donación, son algunas constantes que pueden existir y darse en combinación con la gratuidad y el aparente desinterés (Manghi, 1995; Wuthnow, 1966).

Estamos, en consecuencia, ante un comportamiento complejo en el que aparecen talantes y dimensiones variados. Los voluntarios «altruistas» se mueven por una preocupación de ayuda desinteresada a terceras personas, pero en su decisión pueden estar presentes otros impulsos e intereses que hacen de esta conducta, tal como veremos más adelante, una realidad ambivalente y compleja.

\subsection{LOS VOLUNTARIOS Y SUS REPRESENTACIONES: PERSPECTIVA TEÓRICA}

La preocupación por el estudio de las asociaciones voluntarias no es reciente. Hace siglo y medio, durante su visita a los Estados Unidos, A. de Tocqueville observó que la cooperación voluntaria, la generosidad y el deseo de ayudar a los semejantes se encontraban profundamente arraigados en el corazón americano: «Si ocurre un accidente imprevisto en la vía pública, la gente acude de todas partes hacia la víctima; si inopinadamente se abate una desgracia sobre cualquier familia, mil bolsillos desconocidos se abren para remediarla; donativos numerosos, aunque modestos, vienen a aliviar su miseria» (Tocqueville, 1985: 150). La democracia en América marca un hito a partir del cual cobran auge y sentido las investigaciones sobre las asociaciones voluntarias. Pluralismo y democracia, élites y distribución del poder serán conceptos clave en esta tradición investigadora que, con grandes altibajos y controversias internas, ha continuado hasta nuestros días. 
En nuestro país los estudios sobre el asociacionismo voluntario se inician en los años sesenta, pero su desarrollo posterior ha sido escaso y parcial. Durante un tiempo, las pocas investigaciones que se realizan insisten en la debilidad del asociacionismo español, lo que en alguna medida justifica que no se le dedique especial atención. "Esta premisa se convierte en un tópico de referencia obligada e influye poderosamente en el panorama investigador, ¿para qué estudiar algo tan poco relevante? De aquí en adelante el tema se resolverá generalmente en unas pocas líneas, y sólo se prestará atención a algún tipo de organizaciones voluntarias de crecimiento espectacular» (Cucó, 1992: 243). Habrá que esperar hasta los años ochenta, momento en que comienza a ser relevante su expansión, para que surja el interés por estas asociaciones.

La mayor parte de los estudios que se realizan a partir de esa década adolecen, no obstante, de algunos límites. Gran parte de ellos consideran el fenómeno desde una perspectiva amplia, destacando sus características generales, sus rasgos y dimensiones éticas y sociales (García Roca, 1994; Giner y Sarasa, 1996). Otros tienden a analizar y valorar estas iniciativas atendiendo a los procesos seguidos por el Estado de Bienestar (Sarasa, 1995; Rodríguez Cabrero, 1996; Alonso, 1996). Todos ellos destacan los aspectos organizativos, resaltan el ámbito de actuación, el contenido y los beneficiarios de sus acciones, pero no prestan atención a la dinámica interna, a las diferencias y peculiaridades que presentan estas asociaciones. Por otro lado, el enfoque que siguen se centra en el análisis de los rasgos estructurales y funcionales, lo que implica que la mayoría de ellos dejen de lado el estudio de sus actores y, en consecuencia, no presten atención a las representaciones, los esquemas de pensamiento que guían y movilizan a dichos agentes.

Paradójicamente, este vacío se corresponde con la demanda y la reivindicación que desde los años setenta se hace en la teoría social del «regreso del actor» (Touraine, 1984). A partir de esa década se advierte que son los individuos y los colectivos, de forma conjunta, los que moldean el curso de las sociedades y de la historia humana. Los planteamientos varían, pero se insiste en que el motor último de la «estructuración» son los actores humanos (o agentes), las pluralidades de individuos en su comportamiento cotidiano (Giddens, 1995: 307-313).

Con la reivindicación del lugar y del papel de los agentes en el espacio social se plantea también la importancia y el interés por el estudio de los «intangibles» (las creencias, los valores, las motivaciones, las aspiraciones, las actitudes): «sin volver nuestro centro de interés hacia el nivel de la cultura, hacia el reino de los intangibles y de los imponderables, hacia las variables "blandas", no seremos capaces ni de comprender ni de sobrepasar los obstáculos y los bloqueos que impiden los procesos que llevan al nivel más tangible, institucional "duro" u organizacional" (Sztompka, 1988: 159).

En este caso se presentan igualmente planteamientos y ópticas dispares (Izquieta, 1988), pero existe acuerdo en reconocer que los agentes actúan desde valores, creencias y normas, lo que supone que al analizar su conducta es 
necesario ubicarse en su punto de vista y esto requiere inevitablemente considerar sus esquemas cognitivos, pues dichos esquemas actúan como filtros en su relación con el mundo. Se parte de la premisa según la cual las entidades sociales complejas no son otra cosa que resultados de acciones sociales que emergen. Explicar dichas entidades significa trazar sus raíces en las acciones humanas, y explicar las acciones (entenderlas) es desvelar su significado, las motivaciones que impelen a las personas hacia la acción, así como los valores culturales, las normas y reglas que moldean esa forma de acción.

Esta premisa implica la aceptación y el reconocimiento de que nuestra conducta viene definida por sistemas de significación en virtud de los cuales formamos, ordenamos, sustentamos y dirigimos nuestras vidas. Ese mundo de significados es el que da cuerpo a las creencias, a los símbolos expresivos y a los valores desde los que definimos el mundo, expresamos los sentimientos e ideas y emitimos juicios sobre la realidad que nos rodea (Geertz, 1987).

Lejos de los esquematismos o de las visiones sesgadas que dominaron en décadas anteriores (holismo versus individualismo), en las perspectivas actuales se entiende que esta urdimbre de significados desde los que los individuos interpretamos nuestra existencia y orientamos nuestras acciones se halla asociada e insertada en una red de relaciones sociales organizadas, jerarquizadas y diferenciadas. La acción social no puede por ello entenderse sin tener en cuenta ambas dimensiones, puede variar la perspectiva o puede escalonarse su consideración. En un caso se considerará a la acción social con referencia a la significación que tiene para los que la ejecutan; en otro se la considera en relación a la contribución que hace al funcionamiento de un sistema o de un espacio social, pues el espacio simbólico y el social se integran y retroalimentan (Bourdieu, 1988).

Las relaciones entre estas dos dimensiones son complejas y no pueden establecerse a priori. Los campos de interacción, las instituciones, las organizaciones y los grupos sociales, las formas de estratificación social, constituyen planos con un contenido diferente del que aparece en el espacio simbólico. Los esquemas de significación exigen por ello un tipo de consideración y de análisis distinto al que requiere o implica el análisis de los sistemas simbólicos, pero ello no supone negarlo o desplazarlo.

Por eso, aunque es evidente que en el análisis del altruismo organizado no puede obviarse el estudio de su estructura, composición, configuración, tampoco tiene sentido dejar de lado el mundo de significaciones, valores y representaciones que poseen los agentes que participan en él. Desde aquí se entiende que en las últimas décadas se hayan realizado algunos estudios centrados en esta dimensión. En unos casos se analizan las motivaciones y pautas de voluntarios integrados en múltiples y diferentes asociaciones (Rodríguez Cabrero, 1996). En otros se consideran las visiones y estimaciones que guían a los voluntarios integrados en una organización específica (Funes, 1995), pero lo relevante es que la investigación actual comienza a preocuparse por los agentes de estas organizaciones y tiene en cuenta sus motivaciones, expectativas y actitudes. 
El acceso a estas dimensiones se plantea siguiendo diferentes estrategias, pero no cabe duda que los instrumentos y cauces se atienen a las pautas de la investigación cualitativa, al análisis de los discursos diferenciales de los actores que participan en dichas asociaciones.

Guiados por esta preocupación y por los instrumentos propios de esta perspectiva, nos adentramos en el estudio del voluntariado altruista.

\subsection{ObJETO DE ESTUdio Y PERSPECTIVA METODOLÓGICA}

Con tal fin nos propusimos el estudio de las actitudes, expectativas, percepciones y experiencias de estos voluntarios. Queríamos captar la variedad de situaciones personales desde las que se plantea su cooperación, así como los diferentes campos de atención social donde se lleva a cabo.

Cruz Roja de Valladolid ofrecía las condiciones adecuadas para obtener una muestra significativa de voluntarios con los que mantener una serie de entrevistas abiertas que permitiesen profundizar en tales aspectos.

En esta organización se venían reflejando de forma concreta y tangible los procesos y dinámicas sociales que se perciben en la sociedad española en relación a la emergencia de una nueva solidaridad. En primer lugar, a lo largo de la última década se observa un incremento progresivo de voluntarios que deciden participar en las actividades de la organización. De las 403 personas inscritas como voluntarias en 1987 se pasa, tal como se observa en el gráfico (ver página siguiente), en tan solo ocho años, a tener cerca de 3.000 voluntarios (Callejo e Izquieta, 1996: 47-49).

En segundo lugar, este incremento del número de personas dispuestas a colaborar en Cruz Roja de Valladolid conlleva un cambio en el tradicional perfil sociológico de su voluntarios acorde con el hecho de que en las asociaciones benéfico-asistenciales predominan las mujeres sobre los hombres (Ascoli, 1987; Prieto Lacaci, 1999: 53; 1993: 196). Así, en Cruz Roja de Valladolid se observa la creciente presencia de mujeres voluntarias, especialmente en los nuevos programas y áreas de intervención social, en los que actualmente son mayoría. $\mathrm{Al}$ igual que ocurre en el resto de asociaciones voluntarias, predomina la presencia de voluntarios jóvenes con edades que van de los 16 a los 30 años. Hay que advertir, no obstante, que en esta asociación se hacen presentes personas de diferentes edades. Se observa, asimismo, una diversidad en la capacitación profesional y en la situación laboral de estos voluntarios. Toda esta pluralidad de situaciones pone al descubierto las diferencias sociales, de referentes y de expectativas subyacentes a estas personas.

Por otra parte, en Cruz Roja de Valladolid aparece prácticamente toda la variedad de programas y áreas de intervención social en las que actualmente participan los voluntarios en nuestra sociedad: desde las áreas más tradicionales, como es la asistencia en carretera, hasta las más novedosas, como la teleasistencia o los programas de cooperación al desarrollo. 
Evolución del número de voluntarios de la Asamblea Provincial de Cruz Roja Valladolid

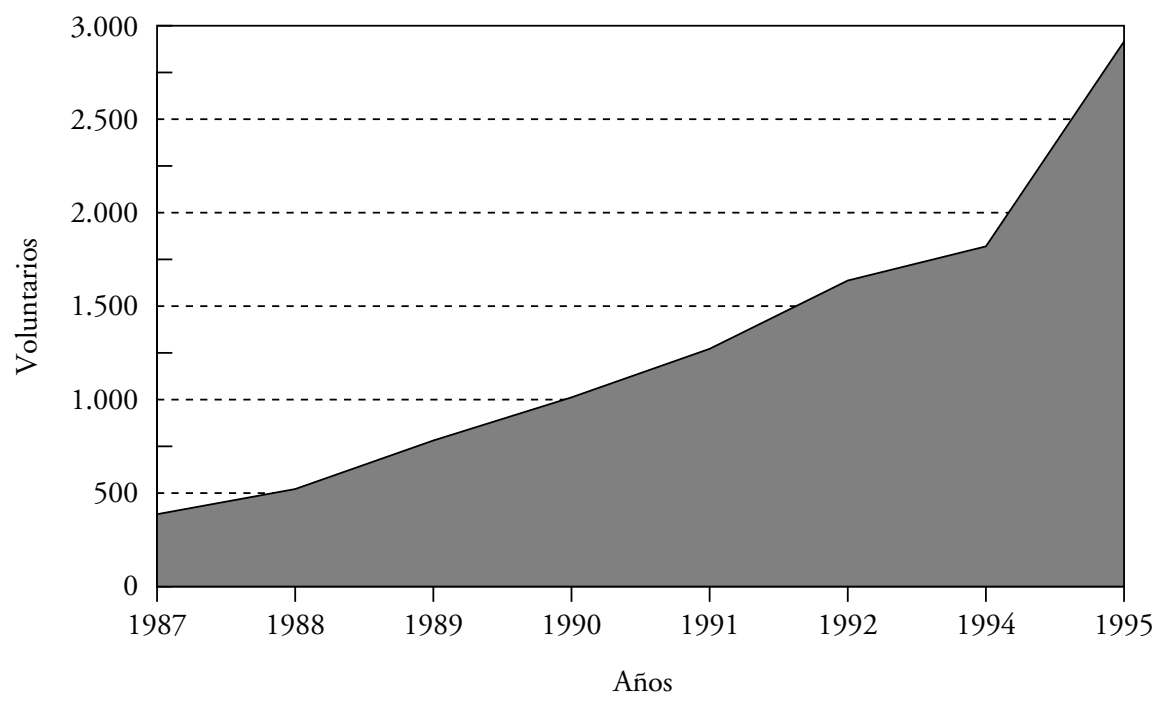

Por último, Cruz Roja ponía a nuestra disposición sus listados de voluntarios, en los que aparecen algunos datos como la edad, el género, el nivel de estudios o el programa en el que se colabora o se desea colaborar, que en conjunto ofrecían una excelente base para la selección de las unidades de análisis.

Así, con el objeto de captar toda la variedad de situaciones desde las que las personas plantean su compromiso, perciben e interpretan la realidad en la que actúan, se utilizaron dos criterios básicos para la selección de los voluntarios a entrevistar: la situación ocupacional del voluntario y el campo o programa de atención social en el que colabora o desearía colaborar. En el cuadro que se adjunta (página siguiente) se ofrece la distribución de los voluntarios entrevistados $^{2}$ en función de estos criterios.

2 Además de las entrevistas a voluntarios, se hicieron entrevistas a los responsables de los distintos programas en los que colaboran los voluntarios y a objetores que trabajaban con los voluntarios, tratando de recoger sus opiniones sobre las motivaciones y expectativas de los mismos. En total se realizaron 56 entrevistas. 
Distribución de los voluntarios entrevistados, según situación ocupacional y área donde se colabora

\begin{tabular}{|c|c|c|c|c|c|}
\hline \multirow[b]{2}{*}{$\begin{array}{c}\text { Situación } \\
\text { ocupacional }\end{array}$} & \multicolumn{5}{|c|}{ Área de colaboración } \\
\hline & $\begin{array}{l}\text { Transporte } \\
\text { Sanitario }\end{array}$ & Toxicomanias & $\begin{array}{l}\text { Servicios } \\
\text { Sociales }\end{array}$ & $\begin{array}{l}\text { Área de } \\
\text { Juventud }\end{array}$ & Totales \\
\hline Estudiantes ............. & 2 & 1 & 2 & 5 & 10 \\
\hline Parados .................... & 3 & 4 & 1 & 1 & 9 \\
\hline Amas de casa ........... & & 1 & 2 & & 3 \\
\hline Trabajadores ........... & 4 & & 4 & & 8 \\
\hline Jubilados ................. & 1 & 1 & 2 & & 4 \\
\hline TOTALES .............. & 10 & 7 & 11 & 6 & 34 \\
\hline
\end{tabular}

Aparte de estos criterios, se tuvieron en cuenta otros como la edad, el género o el nivel de estudios.

\section{LA IDENTIDAD DE LOS VOLUNTARIOS ALTRUISTAS: REPRESENTACIONES, ACTITUDES Y TIPOS DE VOLUNTARIOS}

Los objetivos de la investigación eran descubrir y entender la naturaleza de su decisión, las imágenes y las actitudes que les guían en su cooperación. Para alcanzar estas metas nos planteamos distintas cuestiones centradas fundamentalmente en los motivos que les llevan a hacerse voluntarios y en las representaciones que poseen de las personas a las que ayudan, de la actividad que realizan y de la institución desde la que asumen su compromiso solidario.

\subsection{NATURALEZA Y FUNDAMENTOS DE LA COOPERACIÓN DE LOS VOLUNTARIOS}

Al plantearnos la cuestión de los motivos por los que estos voluntarios deciden cooperar en Cruz Roja nos encontramos ante dos posibles vías de análisis. Se nos presentaba, por un lado, la cuestión de los móviles que impulsan a estas personas a hacerse voluntarias. Surgía, al mismo tiempo, el interrogante de las razones por las que eligen a Cruz Roja para ejercer su cooperación voluntaria.

En los dos casos sus respuestas muestran rasgos similares, pero ofrecen también diferencias. La biografía personal, la edad, las ocupaciones, los estudios realizados y las expectativas profesionales o laborales implican planteamientos y posiciones muy diversos.

Así, al enfrentarnos a la primera pregunta, la de los motivos por los que deciden hacerse voluntarios, todos admiten que su decisión obedece al deseo 
de «ayudar a los demás». Pero, asociadas a esta respuesta «altruista», aparecen también otras justificaciones en las que se ponen de manifiesto valores, intereses o necesidades de distinto signo. Dentro de su diversidad constatamos la presencia de tres clases de razones, cada una de las cuales contiene, a su vez, diferentes matices y expresiones.

Una primera justificación es la de aquellos voluntarios que explican su decisión por su interés en ayudar a "personas necesitadas», pero también por hallar solución a alguna demanda o necesidad instrumental, como adquirir experiencia y formación, tener una ocupación, ampliar su currículum profesional, etc.

Este tipo de justificación suele aparecer en los entrevistados jóvenes que han terminado sus estudios y se hallan sin trabajo, a los que el voluntariado les permite ejercer su profesión en un área próxima a su especialidad, al mismo tiempo que les ayuda a ampliar su curriculum vitae. La descubrimos también en amas de casa, sin otra ocupación, a las que el compromiso voluntario les brinda la oportunidad de salir de su hogar y realizar una actividad no doméstica; en jubilados y parados de diferentes edades cuya meta, al participar en el voluntariado, es la de "continuar en activo». Algunos de los voluntarios «en paro» tienen, además, la esperanza de poder ocupar las plazas remuneradas que Cruz Roja convoca para cubrir determinadas tareas. Saben que en Cruz Roja trabajan profesionales con un salario y confían en poder alcanzar esas plazas.

Otro grupo de explicaciones gira en torno a lo que, en un sentido amplio, se entienden como "intereses expresivos» (Kendrick-Richard, 1991). A través de su cooperación, un sector de voluntarios pretenden, principalmente, desplazar su soledad y aislamiento, mantener o incrementar las relaciones de amistad, tener un espacio de distracción y/o alcanzar un reconocimiento social. El voluntariado les permite resolver urgencias afectivas, alcanzar satisfacciones conectadas con el ámbito de las relaciones humanas y de la estima personal. Se presenta, en definitiva, como un soporte socioafectivo. Estos objetivos se descubren principalmente en los voluntarios del área de juventud (voluntarios jóvenes de 18-25 años) y en los del área de transportes y emergencias, pero, al igual que en el caso anterior, revelan distintos matices.

Se trata de voluntarios jóvenes, de personas que ven en el voluntariado la oportunidad de ampliar sus vínculos sociales, «hacer amigos y conocer a otras personas». Frecuentemente son los propios amigos voluntarios los que les fuerzan a entrar en la organización para poder mantener e incrementar sus relaciones. Otro sector de estos mismos voluntarios reconoce que participa en el voluntariado por el atractivo de algunas de sus actividades (conducir ambulancias, cobertura sanitaria de espectáculos deportivos o recreativos, campamentos, convivencias...). Son tareas que les divierten, les distraen y entretienen. Encontramos también a voluntarios que justifican su decisión por el prestigio y el reconocimiento social que conlleva el dedicarse a los demás. El voluntariado les ofrece la oportunidad de hacer ostentación de su trabajo, pueden contar y hacer partícipes a otros las experiencias, las actividades y sensaciones que 
experimentan en su cooperación. Por otra parte, el aislamiento en el que se encuentran algunas personas en nuestra sociedad, la necesidad de afirmación personal y de comunicarse, les lleva a apuntarse al voluntariado confiando en tomar contacto con otras personas y solucionar así sus carencias. Un número reducido admite también que se hacen voluntarios para aliviar o reducir sus problemas psicológicos. Se trata de personas con trastornos psicológicos a las que el tener una actividad les ayuda a descargar la tensión, al mismo tiempo que les permite satisfacer la necesidad psicológica de encuentro. Animados por algún médico, plantean su cooperación como una terapia, como un remedio a sus problemas.

Existe un tercer frente de explicaciones relacionadas con la preocupación de devolver la ayuda recibida (reciprocidad) o actuar desde lo que se consideran obligaciones o exigencias morales. Se trata de dos actitudes en las que se percibe la presión de las normas morales, pero aquí también se perciben diferencias. Un grupo reducido de voluntarios asume esa opción presionado por el deseo de devolver y agradecer la ayuda recibida directamente o en alguien próximo. Suelen ser personas de más de 40 años que conservan el recuerdo de haber recibido el apoyo de la organización y sienten la obligación de corresponder, de agradecer la ayuda. Pasado un tiempo, cuando se encuentran disponibles, deciden hacerse voluntarios para que otros puedan también conseguir el mismo beneficio que ellos obtuvieron. Encontramos igualmente a otro grupo de personas, generalmente jóvenes, que justifican su decisión recurriendo al sentido del deber, a la exigencia de mantener una coherencia moral, de cumplir y actuar en conformidad con sus principios morales. Se trata de voluntarios que se sienten presionados por una norma moral que les impulsa a cumplir con lo que consideran un deber, la obligación de ayudar a personas necesitadas. Actúan, en definitiva, movidos por un sentido de la responsabilidad que conecta con principios y normas morales que entienden como obligatorios.

En la segunda vía de análisis, la que se refiere a los motivos por los que estos voluntarios eligen a Cruz Roja para ejercer su voluntariado, nos encontramos también ante respuestas similares, pero con matices y diferencias. Al igual que en la pregunta anterior, todos ellos admiten que dicha organización es la que posee las condiciones más idóneas para «ayudar a los demás». Pero advierten, además, que esta organización les permite satisfacer sus expectativas y deseos. Les ofrece medios para ocupar su tiempo libre, para ejercer su profesión, mantener y ampliar sus relaciones, hacer tareas que les atraen y divierten, corresponder a la ayuda recibida, cumplir con sus exigencias solidarias...

Muchos de ellos admiten que es la única organización de voluntarios que conocen. Otros tienen noticia de la existencia de otras organizaciones, pero señalan que ninguna de ellas tiene las cualidades y las características que posee Cruz Roja. Su superioridad se refleja para ellos en la pluralidad de tareas que asume y en la diversidad de campos en los que participa; en la difusión y expansión que posee; en su experiencia; en la disponibilidad de medios y en la infraestructura de que dispone. Advierten también como signos destacados su 
aconfesionalidad, autonomía e independencia ideológica. No faltan los que señalan la prioridad que esta organización concede a la atención de personas cercanas, frente a otras ONGs que se ocupan de realidades lejanas. Todas estas cualidades no se encuentran o no tienen las mismas características en las demás organizaciones de voluntariado que ellos conocen.

Desde estas explicaciones percibimos la diversidad de intereses que subyacen a la opción de estos voluntarios, pudiendo captar, igualmente, la existencia de concepciones e imágenes muy diferentes de su compromiso. A partir de estas premisas y de lo que indican los propios voluntarios analizaremos esas representaciones, tratando de destacar su contenido más significativo.

\subsection{IMÁGENES Y REPRESENTACIONES DE LOS NUEVOS VOLUNTARIOS}

Las representaciones que se hacen los voluntarios de su actividad, de las personas a las que ayudan y de la organización desde la que colaboran poseen, al igual que las motivaciones, un núcleo común: todos conciben su cooperación como una actividad orientada a ayudar a personas necesitadas. Al mismo tiempo, reconocen que desean prestar su ayuda desde la disponibilidad, la experiencia o capacitación y desde los servicios que les brinda la organización. Ahora bien, sus distintas expectativas y los rasgos que definen su opción dan pie a que entre los voluntarios entrevistados aparezcan diferentes concepciones de cada uno de estos tres ámbitos.

\subsubsection{Imágenes de la actividad voluntaria}

Constatamos, en primer lugar, la presencia de voluntarios para los que las personas a las que ayudan tienen unas carencias o problemas cuyo tratamiento exige el uso de técnicas especiales. Piensan, en consecuencia, que el voluntario, aunque debe intervenir con un sentido "altruista», debe también poseer una cualificación profesional. El voluntario no debe improvisar, ni debe plantearse su acción guiado únicamente por su «buena voluntad». Para éstos, la acción voluntaria, aunque altruista, debe ser profesional, eficaz; debe estar programada, estudiada y definida. Cuidar o atender a un drogadicto, a un herido en la carretera, a un anciano o a un deficiente no son tareas que puedan o deban plantearse espontáneamente. Esto explica que, según ellos, la acción voluntaria no debe dejarse en manos de «inexpertos», y determina igualmente su preferencia a participar en tareas o áreas de atención para las que se consideran especialmente dotados o preparados.

Un segundo grupo de voluntarios entiende la ayuda como una actividad "heroica». Para estos voluntarios, la preparación técnica y la «buena voluntad» no son el único requisito de la acción voluntaria. A su juicio, el voluntario debe poseer, además o principalmente, una intuición, unas habilidades o cuali- 
dades especiales. Al ser, desde su punto de vista, una acción orientada a prestar ayuda en situaciones especiales, los voluntarios deben tener una personalidad acorde con una actividad que conlleva riesgos y frecuentemente resulta comprometida, esforzada y costosa. Piensan que estas dotes no se adquieren con estudio o en cursos de formación, sino que se hallan conectadas a determinados valores y actitudes, como la entrega, la disponibilidad, la decisión, el «heroísmo», la audacia.

Existe un tercer grupo de voluntarios que entiende su cooperación como una actividad "espontánea», que no precisa ningún tipo de requisito o cualificación profesional. Conciben el voluntariado como una acción "voluntariosa». Es decir, como el deseo de ayudar a las "personas necesitadas» o a la institución en «algo», «en lo que sea»; no les importa en qué ni cómo. Desde esta concepción se entiende que la tarea del voluntario consiste, principalmente, en acompañar y apoyar a personas que se encuentran solas y tienen dificultades de movilidad y de relación, o como un apoyo y/o complemento de las tareas de los profesionales. Con su cooperación buscan reducir el sufrimiento y mejorar las condiciones de vida de las "personas necesitadas", aportándoles compañía, afecto y atenciones de todo tipo, o bien favorecer el cometido de la institución, aunque sea a un nivel insignificante (llevando cartas, haciendo fotocopias, etc.). De ahí su disponibilidad para asumir cualquier tarea que se les encomiende, siempre que sea compatible con sus capacidades y con sus limitaciones de tiempo.

\subsubsection{Imágenes de las personas que reciben la ayuda voluntaria}

Además de las imágenes sobre la actividad, los voluntarios tienen también diferentes representaciones de las personas a las que atienden y del modo en que deben relacionarse con ellas. En principio, todos están de acuerdo en que las personas a las que ayudan son personas con alguna carencia, con alguna limitación o problema, pero discrepan en la representación que se hacen de ellas y del trato que se les debe dar. Al igual que en el caso anterior, nos encontramos con tres representaciones que conectan, en gran medida, con las señaladas más arriba.

Los voluntarios que entienden su acción como una actividad «técnica» $y$ "profesional», conciben a las personas a las que ayudan como "pacientes", es decir, como personas con problemas específicos (enfermedad, lesión, discapacidad, adicción...) que requieren la intervención de un profesional especializado. En esta representación la persona a la que se atiende no se encuentra en la misma condición que el voluntario; por eso se la valora de un modo específico y se le ofrece un trato diferenciado. Por ejemplo, en la relación que se establece entre el enfermo y el médico, el toxicómano y el psicólogo o el inmigrante y el trabajador social, unos y otros parten de una situación de desigualdad. En todos estos casos la interacción se plantea desde una posición diferente. El pro- 
fesional no ofrece al paciente sus cualidades personales, sino su capacitación técnica. La relación entre ambos (paciente y profesional) está mediada por las actividades que el profesional realiza sobre el problema o la enfermedad del paciente. Es decir, la relación entre paciente (toxicómano) y el profesional (psicólogo) se plantea desde la actividad (entrevista clínica) que el profesional realiza sobre el problema (drogodependencia) del paciente. Con lo cual la interacción entre ambos es asimétrica e indirecta, pues se plantea a partir de los diferentes roles y status que la persona necesitada y el voluntario asumen y tienen cuando se encuentran.

A diferencia de los anteriores, los voluntarios que entienden su acción como una actividad "heroica» perciben a las personas a las que atienden no como "pacientes», sino como "usuarios». Es decir, personas que demandan una serie de servicios de la institución en la que ellos colaboran. En este caso la relación que se plantea entre el «usuario" y el voluntario está mediada por la institución. Se trata, principalmente, de una relación entre una persona que demanda un servicio y una institución que lo presta. La intervención del voluntario queda por ello relegada a un segundo plano, como agente de una organización en la que colabora. De aquí se desprende que el voluntario no se sienta comprometido ni especialmente preocupado por los problemas y las carencias del «usuario», ni por su condición o situación personal. Por ejemplo, el conductor de ambulancias no tiene por qué actuar sobre las heridas del accidentado ni preocuparse de su situación personal. Del mismo modo, quien administra metadona en el departamento de toxicomanías, o lleva el control administrativo de los toxicómanos, tampoco está obligado a interesarse por el estado psíquico del toxicómano o por su situación personal, familiar o social.

El contacto entre el voluntario y el usuario es en este caso reducido. $\mathrm{Su}$ relación es producto de la convergencia de dos trayectorias distintas: por un lado, el usuario que demanda un servicio a la institución y a ella se lo agradece; por otro lado, el voluntario que colabora con la institución prestándole su tiempo y dedicación y, por tanto, es de ésta y no del usuario de quien espera agradecimiento y consideración.

Por último, los voluntarios que asumen su actividad de manera espontánea consideran que su ayuda se dirige a "personas necesitadas». El significado y el contenido de esta expresión son imprecisos, pero hacen referencia a carencias humanas presentes en algunos individuos o grupos de nuestra sociedad que tienen dificultades en su vida por no disponer de personas que les atiendan, por carecer de vínculos familiares o por hallarse limitados en su movilidad. La diferencia que presentan estas personas con los voluntarios que las atienden es coyuntural. Se distinguen de ellos porque «necesitan» de su apoyo para estar en condiciones óptimas. Por ejemplo, un anciano para estar en condiciones satisfactorias debe experimentar el reconocimiento de los otros, debe sentirse acompañado, tener alguien con quien comunicarse. Piensan estos voluntarios que las «personas necesitadas» no sólo demandan la intervención de un profe- 
sional especializado o la prestación de unos servicios específicos, sino también atenciones conectadas con cualidades humanas como el afecto, la comprensión, la compañía. Son demandas vinculadas a un campo de bienes relacionales que no pueden ser satisfechas desde el mercado ni desde la protección institucional o pública, pues habitualmente en este ámbito los servicios y la propia ayuda se ofrecen por profesionales que desempeñan su competencia desde una institución en la que han sido elegidos desde la base de su cualificación técnica y plantean un tipo de vinculación con los demandantes de ayuda impersonal, sin afecto ni entusiasmo. El voluntario con su ayuda trata de suplir estos límites del apoyo institucional, lo que le lleva a asumir y entender su relación con el demandante como una relación cercana, afectiva, "de persona a persona».

\subsubsection{Imágenes de la organización desde la que actúan}

Los voluntarios tienen también distintas concepciones de la organización desde la que prestan o realizan su servicio voluntario. Al plantear los motivos por los que eligen dicha organización para realizar su voluntariado ya advertíamos la diversidad de razones que justifican su opción. Atendiendo a esas razones y en consonancia con las representaciones descritas anteriormente, podemos constatar la existencia de tres representaciones distintas de la institución y, paralelamente, de tres posiciones o actitudes ante ella.

El grupo de voluntarios que entienden su actividad como una tarea profesional, aunque aceptan que colaboran en una asociación de voluntarios, encuentran en ella rasgos y características que no aparecen en el resto de organizaciones. Sus diferencias radican en la experiencia, en la independencia y aconfesionalidad que posee y, sobre todo, en los recursos y medios técnicos y profesionales que tiene para realizar su labor social, especialmente en servicios sociales, que hacen de ella una organización altamente especializada y "experta». Consideran, además, que la misión de esta organización es la de atender a colectivos con problemas, pero piensan también que debe intervenir, principalmente, en aquellos problemas y con aquellas personas insuficientemente atendidas desde las Administraciones, completando y ampliando así sus servicios.

Los voluntarios que conciben a las personas a las que ayudan como «usuarios» y entienden su acción como algo "heroico» piensan que esta organización es mucho más que un instrumento para la acción voluntaria o un lugar donde se realiza una actividad profesional. La sienten como una institución cercana, se identifican de tal modo con ella que la consideran como su «casa». Se sienten, por ello, orgullosos de participar en sus actividades, de llevar sus símbolos y emblemas. Experimentan como propios sus éxitos y sus fracasos. Cuando hablan de ella lo hacen en primera persona: «nosotros los de Cruz Roja». Este talante les lleva a implicarse en sus órganos de gestión y a participar activamente en su estructura interna. Asumen un talante crítico con su funciona- 
miento y adoptan frente al exterior una conducta proselitista, defendiendo a la organización de posibles ataques y animando a otras personas a integrarse y a participar en sus actividades.

Finalmente, los voluntarios que entienden su cooperación como una ayuda orientada a "personas necesitadas" asumen que están en una organización humanitaria con las mismas funciones y características que las demás organizaciones de voluntariado. Esta visión les lleva a interesarse, especialmente, por la situación humana de las personas a las que atienden y a dejar en un segundo plano la institución, lo que conduce a que no se preocupen de su funcionamiento y a que no se interesen por lo que sucede dentro de ella. Se desentienden de las tareas administrativas, no les preocupa el modo en que se organiza y estructura la ayuda y tampoco se plantean el participar o intervenir en la gestión de la organización. Todo ello supone que para éstos la organización es el medio o cauce a través del cual se accede a las personas necesitadas. Podríamos decir que desde esta posición se percibe a la organización como una mera agencia de contacto entre el voluntario y la persona necesitada.

\subsection{TiPOlOGía DE LOS NUEVOS VOLUNTARIOS}

Este conjunto de representaciones y actitudes revela la heterogeneidad de los nuevos voluntarios; descubre, no obstante, la presencia de algunas constantes que les asemejan y aproximan. Atendiendo a lo señalado hasta aquí y retomando las distintas dimensiones observadas en nuestro análisis, constatamos la presencia de tres tipos de voluntarios, cada uno de los cuales presenta una concepción diferente del voluntariado con rasgos y características definidos y específicos.

Un primer tipo está compuesto por los voluntarios centrados principalmente en la actividad que realizan. Se preocupan de las personas a las que atienden, pero dan prioridad al trabajo y a las estrategias y técnicas que se emplean en la intervención. Esto explica su afán por participar en tareas que exigen una capacitación (Servicios Sociales, Toxicomanías, Programas de Juventud), así como su deseo de realizar cursos de formación, de especializarse y de ejercer su profesión.

Dentro de este tipo se pueden distinguir, no obstante, dos grupos: uno formado por jóvenes en paro, con una cualificación técnica o profesional, y preparados en determinados servicios de asistencia (auxiliares de clínica, trabajadores sociales, educadores...), cuya preocupación fundamental es la de practicar su especialidad y conseguir una experiencia profesional. Y otro compuesto por voluntarios que también poseen una capacitación profesional pero que no han podido ejercer su especialidad por haberse dedicado a otras ocupaciones; se trata principalmente de amas de casa que vieron truncada su profesión por tener que dedicarse a la atención de sus hijos, al cuidado de la familia y a las tareas del hogar. Este segundo grupo se preocupa también por la actividad, 
pero, a diferencia de los anteriores, no les interesa adquirir experiencia y no tienen expectativas profesionales, sino que su afán es el de satisfacer una cierta frustración y alcanzar una realización personal que no obtienen en su vida privada o en sus trabajos habituales.

Los incentivos o la gratificación que persiguen y que obtienen estos voluntarios no proceden, en ambos casos, de la gratitud o del reconocimiento que les otorgan las personas a las que atienden, sino de la oportunidad de ejercer su profesión y de poder realizarse profesionalmente. Los conocimientos que adquieren y el enriquecimiento personal que consiguen compensan el tiempo y las energías que dedican al voluntariado, justificando así su continuidad en la organización.

Constatamos también la existencia de un segundo tipo en el que incluimos a los voluntarios cuyo centro de interés y preocupación se sitúa en la institución desde la que cooperan. Tal como hemos visto, para un sector de voluntarios el deseo de «ayudar a los demás» queda supeditado, en gran medida, al deseo de integrarse en Cruz Roja y poder participar en su dinámica y estructura interna. Su cooperación no se guía por el afán de mantener relaciones con personas necesitadas ni por el deseo de ejercer la profesión o alcanzar una realización personal, sino por la pretensión de pertenecer a una institución que, en unos casos, les brinda la oportunidad de relacionarse con los amigos y, en otros, les ofrece la posibilidad de mantener o ampliar relaciones con otras personas. Todo ello en un clima gratificante pues, además, las actividades que realizan les resultan agradables, les divierten y entretienen.

$\mathrm{Al}$ igual que en el tipo anterior, aquí también pueden distinguirse dos subgrupos con diferentes características. Están, por un lado, los voluntarios jóvenes ocupados principalmente de la atención sanitaria en espectáculos y en concentraciones masivas, para los que la organización se presenta como un lugar de encuentro, un espacio de convivencia en el que pasan sus ratos de ocio, hacen amigos y amplían sus redes de amistad, sintiéndose afectivamente realizados en una organización que les reporta reconocimiento, prestigio y espacios de comunicación y de relación.

Por otro lado, encontramos a los voluntarios pertenecientes, principalmente, a las áreas de socorro y ayuda en carretera, las más tradicionales de esta organización, que se sienten identificados no sólo con los compañeros, sino con Cruz Roja como institución. Son los voluntarios que llevan muchos años en la institución. En algunos casos, su vinculación a la misma se remonta al momento en que hicieron su servicio militar en los puestos de socorro de la organización. Estos voluntarios consideran a la institución como algo propio, se sienten orgullosos de pertenecer a ella, participan activamente de sus preocupaciones, de sus éxitos y de sus fracasos. Asumen su cooperación experimentando también sensaciones agradables, pues la actividad que realizan y el ámbito desde el que cooperan les aporta emociones y vínculos que les gratifican y compensan, lo que refuerza y potencia su identificación con la organización. 
Los incentivos que reciben estos voluntarios no proceden de las personas a las que ayudan pues, tal como indicábamos más arriba, las ven como «usuarios» de los servicios que presta la institución. El contacto que mantienen con ellas es, además, esporádico y superficial, lo que no permite que se planteen relaciones profundas. Tampoco tienen expectativas profesionales ni ansían ejercer como profesionales o técnicos. Su satisfacción la obtienen, principalmente, del grupo humano del que forman parte y de las emociones o sensaciones que les producen las tareas que realizan. La amistad que desarrollan, la convivencia con otras personas o el orgullo de pertenecer a una institución que posee un prestigio social y el participar en tareas arriesgadas (conducción de ambulancias) son alicientes que les satisfacen y gratifican.

El interés y la preocupación de estos voluntarios se centran, por tanto, en la relación que mantienen con los compañeros y con los responsables de la institución. Es de ellos, y no de las personas a las que ayudan, de quienes esperan y desean el reconocimiento y la valoración de su trabajo.

Esto explica, asimismo, que no se preocupen ni se interesen excesivamente por las actividades que se realizan desde la organización. El atractivo que pueden tener determinadas tareas queda en un segundo plano, pues lo importante para ellos, lo que explica su continuidad en la institución durante muchos años y la gran cantidad de tiempo que le dedican, es el sentimiento de pertenencia a un colectivo y los fuertes lazos de amistad que se crean con el resto de compañeros.

Un tercer tipo está compuesto por voluntarios que centran su opción en el cuidado de "personas necesitadas». Éstos entienden que su misión es la de prestar un servicio directo a personas que están en dificultades. La prioridad que conceden a la atención y a la relación con estas personas explica que no tengan preferencias por intervenir en determinadas áreas y que tampoco se interesen por la institución desde la que intervienen. Lo importante para ellos son las personas a las que atienden, dejando en un segundo plano el modo de ejercer la ayuda y el ámbito desde el que se realiza. Este talante les lleva a entender que para ser voluntario no es preciso poseer una cualificación especial ni unos conocimientos específicos. Así se entiende también su despreocupación por los cursos de formación y su pasividad o distanciamiento ante lo que sucede en el seno de la organización.

Estas constantes presentan, no obstante, algunos matices en función de la experiencia, de la visión que tienen de la ayuda y de las propias compensaciones que esperan alcanzar o de las expectativas que tienen sobre su cooperación. Se constata, por un lado, la presencia de voluntarios, predominantemente jóvenes, que participan por primera vez en estas tareas. Junto a éstos encontramos a personas mayores que recibieron ayuda en el pasado directa o indirectamente (familiar próximo) y se sienten obligados a corresponder en la misma medida. Todos ellos asumen su cooperación guiados por un impulso difuso de ayudar a los demás, sin plantearse el sentido, el significado y el alcance de su cooperación. Piensan que la acción voluntaria se justifica en sí misma, lo que 
les lleva a desentenderse de las causas por las que aparecen las situaciones de necesidad y a no prestar atención al contexto en el que realizan su cooperación. El estímulo que les impulsa a hacerse voluntarios y las compensaciones que esperan obtener con su cooperación no dependen o proceden de las actividades que realizan ni de la institución desde la que actúan, sino de las personas a las que atienden y de cumplir con lo que consideran que es su «deber» u obligación. La relación que mantienen con ellas les reporta un enriquecimiento humano, les ofrece la posibilidad de sentirse útiles, de acceder a problemas que les eran desconocidos anteriormente. Todo ello les produce una satisfacción que determina su continuidad como voluntarios.

Por otro lado, dentro de este mismo tipo percibimos la presencia de un tercer grupo formado básicamente por jóvenes que tienen, igualmente, una concepción «idealista» de su cooperación y participan del mismo impulso moral, pero, a diferencia de los anteriores, pertenecen o han colaborado anteriormente en otras organizaciones de voluntarios. Poseen, en consecuencia, una experiencia de la acción voluntaria que les lleva a enfrentarse a su cooperación valorando el alcance y los límites de su acción. Entienden su cooperación con un sentido crítico, plantean y analizan las causas del malestar de las personas a las que atienden, ponen de manifiesto y denuncian las situaciones y realidades que consideran injustas. Desde esta actitud, asumen su ayuda como una actividad orientada tanto a la ayuda individual como a la transformación de las estructuras que generan las situaciones de necesidad en las que intervienen. Por otro lado, las gratificaciones que obtienen proceden de su convicción de estar trabajando para mejorar no sólo la vida de las personas, sino también las estructuras que producen su sufrimiento. Tienen conciencia de estar contribuyendo al cambio en las condiciones de vida de excluidos y menesterosos.

Desde esta tipología podemos captar las tendencias que dominan en estos nuevos voluntarios. Ahora bien, el predominio de determinados aspectos no significa que los tipos mencionados sean nítidos y rígidos. La tipología que presentamos no es más que una división artificial en tres núcleos de un espacio triangular continuo que va desde un vértice a otro sin que existan fronteras cerradas entre ellas. Por otro lado, la concepción que cada voluntario tiene de su condición no es inamovible, sino que la experiencia les lleva, a veces, a una reelaboración de su posición, de lo que piensan y realizan como voluntarios, provocando, en algunos casos, el paso de un tipo a otro.

Atendiendo a estos matices y teniendo en cuenta la flexibilidad de estos tipos, presentamos un cuadro (página siguiente) en el que se pueden ver, esquemáticamente, las relaciones y las conexiones, las diferencias, los rasgos y las constantes que hemos reseñado a lo largo de nuestra exposición. 
Tipología de los nuevos voluntarios

\begin{tabular}{llll}
\hline & \multicolumn{1}{c}{ TIPOI } & \multicolumn{1}{c}{ TIPO II } & TIPO III \\
\hline & \multicolumn{1}{c}{ Instrumentales } & \multicolumn{1}{c}{ Expresivas } & \multicolumn{1}{c}{ Morales } \\
\cline { 2 - 4 } $\begin{array}{l}\text { Motivaciones de la } \\
\text { colaboración }\end{array}$ & $\begin{array}{l}\text { Búsqueda de expe- } \\
\text { riencia y formación. } \\
\text { Ocupar el tiempo } \\
\text { libre. } \\
\text { Ejercer la profesión. }\end{array}$ & $\begin{array}{l}\text { Vivir nuevas expe- } \\
\text { riencias. } \\
\text { Conocer a otras per- } \\
\text { sonas. } \\
\text { Prestigio social. } \\
\text { Terapia ocupacional. }\end{array}$ & $\begin{array}{l}\text { Reciprocidad. } \\
\text { Obligación moral. }\end{array}$ \\
& &
\end{tabular}
$\begin{array}{llll}\begin{array}{l}\text { Ejes en los que se centra } \\ \text { su cooperación }\end{array} & \text { La actividad profesio- } & \text { La organización desde } & \begin{array}{l}\text { Las personas a las que } \\ \text { nal. }\end{array} \\ \text { la que colaboran. } & \text { atienden. }\end{array}$

Actividad "heroica" (requiere audacia, valor, entrega...). tación técnica específica).

Imágenes de la actividad que realizan

Actividad "espontánea" (no requiere ningún tipo de cualificación).

«Usuario».

«Persona necesitada».

Imágenes de las personas «Paciente».

a las que ayudan

Imágenes de la institución

en la que colaboran
Organización con «Entidad» con la que medios técnicos. se sienten «identificados».
Mera "agencia» que pone en contacto al voluntario con "personas necesitadas».
Incentivos que impulsan su continuidad como voluntarios

Perfil sociológico
Jóvenes con estudios superiores.

Amas de casa y trabajadores con deseos de realización profesional.
Aprendizaje y expe- Sentimiento de perteriencia profesional. nencia e identificación con el grupo humano.

Estudiantes.

Trabajadores, parados y jubilados vinculados desde antiguo a la organización.
El reconocimiento y agradecimiento de las personas a las que ayudan.

Jóvenes que participan por primera vez en el voluntariado.

Personas que recibieron ayuda en el pasado.

Jóvenes con un talante crítico. 


\section{LOS NUEVOS VOLUNTARIOS: ANÁLISIS COMPARATIVO Y HORIZONTES DE INTERPRETACIÓN}

El análisis realizado nos acerca a la comprensión de los aspectos más representativos de estos voluntarios, nos permite captar sus valores e intereses, así como las representaciones y actitudes que definen su conducta. Partiendo de esas premisas podemos extraer algunas conclusiones sobre estos nuevos actores sociales; estamos en condiciones de relacionar nuestros resultados con los que aportan otros estudiosos; es posible, asimismo, adelantar una explicación de su existencia y expansión.

\subsection{UNIDAD Y DIVERSIDAD DE LOS VOLUNTARIOS}

Los resultados alcanzados muestran la diversidad de matices que presentan los nuevos voluntarios, la heterogeneidad de sus motivaciones e imágenes. Descubren, también, la presencia de rasgos comunes y coincidentes. Su decisión de cooperar, en la que se combinan motivos altruistas y utilitarios; su visión de la organización, como la más eficiente y eficaz, así como su talante y comportamiento, ajenos a premisas ideológicas, son similares en la mayoría de ellos. Apoyados en estos hechos y en lo que revelan distintos estudios del voluntariado, podemos establecer una aproximación entre estos voluntarios y los que cooperan en otras organizaciones, tratando de captar su proximidad y sus diferencias.

Al retomar los trabajos realizados sobre los voluntarios altruistas comprobamos la presencia de diferentes enfoques y perspectivas. Dentro de esa disparidad predominan, no obstante, los estudios centrados en el análisis de sus motivaciones (EDIS, 1987; Demoscopia, 1994; Funes, 1995), del contexto en el que aparecen y se expanden (Casado, 1992; Sarasa, 1995; Rodríguez Cabrero, 1996; Giner, 1995) y del talante y actitudes que definen y caracterizan su comportamiento (Funes, 1993; García Roca, 1994; Giner y Sarasa, 1996; Alonso, 1996).

La reflexión sobre los móviles que provocan el compromiso de los voluntarios se polariza y sitúa, básicamente, en torno a dos frentes. Para un grupo, los voluntarios se comprometen y actúan guiados, unilateralmente, por una sola clase de motivaciones. Se insiste, por un lado, en el carácter altruista y solidario de su compromiso, destacando, por ejemplo, que "las características que conforman su perfil son: desinterés, responsabilidad, sin remuneración económica, acción realizada en beneficio de la comunidad, voluntad de servir, actividad solidaria y social, su trabajo no es una ocupación laboral habitual, es una decisión responsable que proviene de un proceso de sensibilización y concienciación» (Bernardo y Renes, 1986). En el polo opuesto, la acción voluntaria se asocia con la búsqueda de los propios intereses y con la solución o satisfacción de carencias personales: «Con seguridad, la mayoría de personas dedica tiempo 
a actividades voluntarias declarando actuar en nombre de los grandes ideales humanistas... Pero más allá de estos referentes, es sobre todo el placer de encontrar al otro, el deseo de valoración social, la ocupación del tiempo libre lo que constituyen las motivaciones esenciales del voluntariado» (Lipovestki, 1994: 147)

Frente a estas visiones unilaterales nos encontramos con la explicación de otros estudiosos para los que la cooperación de los voluntarios se guía tanto por la generosidad, es decir, por el deseo de ayudar a los semejantes, como por las gratificaciones que obtienen a cambio. En este caso se advierte que los voluntarios mezclan y combinan distintos argumentos, actúan movidos por diferentes móviles (Demoscopia, 1994; Funes, 1995). Los resultados obtenidos en nuestra investigación coinciden con esta visión. Las personas entrevistadas apuntan más de un argumento, tal como vimos, y justifican su decisión aportando distintas razones. Detrás de cada tipo de voluntario aparece el deseo de ayudar a los demás, pero se descubren también diferentes justificaciones de su opción.

El contexto y las condiciones en las que emergen y se expanden estas iniciativas son igualmente objeto de atención en diferentes trabajos. Los autores que abordan estos aspectos los asocian, mayoritariamente, a la dinámica y a los procesos seguidos por el Estado de Bienestar: «El asociacionismo voluntario y comunitario ha venido a constituirse como una de las dimensiones semioculta, pero fundamental, del avance contemporáneo del Estado de Bienestar» (Alonso, 1996: 105). Vinculan su presencia al incremento de las necesidades sociales, a la escasez de recursos públicos y a la ineficacia en las prestaciones sociales (Rodríguez Cabrero, 1996: 20). Basan su explicación en los procesos de contracción seguida por la protección pública y en la consiguiente expansión de otras vías o formas de asistencia, así como en la propia dinámica de la sociedad. «Las asociaciones altruistas han demostrado con la práctica que pueden erigirse en plataformas para las nuevas demandas democráticas... y no son otra cosa que la superficie... de la integración y vertebración de una sociedad... rompiendo las limitaciones que impone en la actualidad el debilitamiento del Estado de Bienestar» (Rodríguez Ibáñez, 1995: 55-56).

De los datos extraídos en nuestro estudio se confirma que los voluntarios se ocupan de sectores de población insuficientemente protegida y a los que no llega la protección privada o pública (personas con discapacidades, solas, con adicciones...). Ahora bien, desde ese enfoque no se atiende a toda la gama de aspectos que presenta el colectivo de voluntarios; se ofrece una imagen estructural y funcional de su existencia, pero no se penetra o profundiza en los factores que explican la emergencia de los colectivos a los que atienden y en las motivaciones y urgencias que guían a los voluntarios. Estos cooperan impulsados por las necesidades de individuos, pero también por sus propias preocupaciones. Por otro lado, al considerar las motivaciones por las que cooperan observamos que no tienen conciencia de los límites que presenta la protección pública, ni valoran sus posibles problemas o carencias. 
Los trabajos en los que se analizan el talante y las actitudes que guían a los voluntarios conectan a este colectivo con el impulso seguido, en las últimas décadas, por la Sociedad Civil y con los nuevos movimientos sociales (Tomai, 1991; García Roca, 1994: 62). Para determinados autores: «El incremento del voluntariado puede ser entendido desde el descrédito que sufren en los últimos años las organizaciones políticas... Las organizaciones altruistas aparecen en el momento actual con una capacidad de movilización y convocatoria significativa. Podemos hablar de un desplazamiento desde la política convencional a estas formas no institucionales de actividad pública» (Funes, 1995: 198; 209).

Sin embargo, si atendemos a las actitudes y al comportamiento que revelan los voluntarios de Cruz Roja comprobamos que tan sólo una parte reducida de los voluntarios del tercer tipo plantea su cooperación con un talante crítico y actúa por un bien colectivo. La mayoría se preocupa por los problemas de terceras personas, pero no manifiesta un interés especial por transformar la realidad o el entorno en el que se plantea su cooperación. Su interés se sitúa en la atención y relación con las personas, en las actividades que realizan o en la institución desde la que colaboran. Por eso, su compromiso difiere claramente del que presentan los voluntarios que participan en otras asociaciones y organizaciones (ONGs) y queda muy lejos de los rasgos que caracterizan a los nuevos movimientos sociales (Offe, 1988; Dalton, 1992; Touraine, 1990).

\subsection{VOLUNTARIADO Y ACCIÓN COLECTIVA}

Los datos obtenidos en nuestra investigación y, especialmente, el análisis de las motivaciones que guían a los voluntarios entrevistados nos permiten, igualmente, conectar y relacionar su conducta con las teorías de la acción colectiva.

El conjunto de argumentos que utilizan los voluntarios para justificar su compromiso se sitúa, según veíamos, sobre tres planos. Expresan, por un lado, su interés en ayudar a personas necesitadas, pero señalan, también, su pretensión de resolver, en unos casos, sus necesidades «instrumentales» y «expresivas» $y$, en otros, de cumplir con lo que consideran que es su "deber». Si atendemos a estas explicaciones comprobamos que su argumentación guarda relación con distintas interpretaciones de la acción colectiva.

En principio, parecen conectar con el enfoque de la «elección racional», cuyo argumento principal se apoya en el supuesto (común en el ámbito de la microeconomía) de que las acciones individuales se orientan principalmente al resultado, son racionales, en sentido instrumental, y egoístas (Olson, 1972).

Sin embargo, los tres supuestos en los que se sustenta esta teoría: 1) los individuos buscan siempre y deliberadamente su interés personal; 2) con frecuencia lo hacen sin mediar interacción social; 3) hay un ser omnisciente que establece recompensas simples y fáciles de calcular, no son suficientes para explicar los distintos matices presentes en el comportamiento de estos volunta- 
rios. La mayoría de los voluntarios entrevistados contempla la posibilidad de beneficiarse al actuar solidariamente, pero no efectúa un cálculo minucioso de los beneficios. No planifican ni imaginan premeditadamente el equilibrio entre costes y beneficios. Todos ellos confiesan, además, abiertamente su deseo de ayudar a otros, revelan un interés social que se mezcla, como hemos visto, con otras motivaciones que pueden ser instrumentales, expresivas o morales.

Algunos voluntarios expresan también un talante próximo al enfoque defendido por un grupo de estudiosos que aceptan las micromotivaciones racionales y egoístas de la acción colectiva, pero fijándose no en el resultado, sino en el propio proceso de la cooperación. Para estos analistas, la participación en la acción colectiva se produce no porque exista un interés especial en el resultado de la acción, sino porque los actores disfrutan participando o porque de ese modo se sienten realizados (Hirschman, 1986; Scitovski, 1988).

En el caso de los voluntarios de Cruz Roja comprobamos que un sector explica su compromiso por la satisfacción que obtiene en lo que realiza, es decir, porque disfruta con su actividad. Ahora bien, puede decirse que, al igual que sucede en los voluntarios de otras organizaciones (Wuthnow, 1996), el sentirse bien y el experimentar sensaciones gratas no constituye la motivación principal para ayudar a los demás, sino que es más bien una contrapartida, una consecuencia o un subproducto de su acción.

En un grupo de voluntarios se percibe, asimismo, la preocupación de alcanzar un reconocimiento social y la necesidad de encontrar un contenido o un significado a su vida cotidiana. Su cooperación les ofrece la posibilidad de encontrarse a sí mismos perdiéndose en una finalidad absorbente. Al participar en Cruz Roja se funden y confunden con una organización que, además de aportarles un espacio social en el que situar sus preocupaciones, les ofrece un marco en el que ocupar su tiempo y en el que proyectar sus afectos. Construyen y refuerzan su identidad desde la identidad de una colectividad. Esta actitud conecta, sin duda, con la explicación que aducen algunos analistas, para los que la acción colectiva se plantea como una solución a la necesidad generada en nuestra sociedad de hallar un ámbito de integración y sentido. Las modernas y racionalizadas relaciones sociales han dejado de proporcionar puntos de referencia consistentes para construir la identidad individual. Los individuos buscan nuevos grupos y nuevos enclaves sociales en los que encontrar soportes y referencias. Las organizaciones de voluntarios aparecen por ello como un espacio de identidad en el que determinados sujetos encuentran un sentido a su vida (Pizzorno, 1989; Melucci, 1989).

Algo similar puede decirse del planteamiento seguido por aquellos autores para los que el compromiso en la acción colectiva procede de la presión que sobre los individuos ejercen los grupos primarios (redes familiares y de amistad) (McAdam, 1986; Snow, Zurcher y Ekland, 1980). En nuestro caso vemos que, efectivamente, algunos voluntarios admiten como razón de su participación los vínculos familiares y el deseo de conservar sus relaciones de amistad, pero, tal como indicamos anteriormente, esa justificación se da en un grupo reducido. 
El razonamiento de los voluntarios que asumen su cooperación desde el afán de corresponder a la ayuda recibida (reciprocidad) o de cumplir con lo que consideran que es su obligación conecta con la perspectiva que pone el acento en las normas sociales (Parsons, 1970; Elster, 1990; Knoke, 1990). La acción colectiva se explica, en este caso, no sólo desde la lógica del egoísmo y desde las micromotivaciones, sino atendiendo a normas sociales compartidas por otros y basadas en la aprobación o el rechazo de otros (Elster, 1990: 121). Esas normas proporcionan una razón para actuar, para ser voluntario. Se trata, por tanto, de un comportamiento definido no tanto por los resultados que se esperan obtener o por la rentabilidad de la acción, sino por el peso y la presión que ejerce el referente del deber (Elster, 1997: 44-54).

Este enfoque nos permite captar el papel y la relevancia que para determinados voluntarios tienen sus principios y creencias, muestra la presencia de criterios de racionalidad y de referentes de conducta que quedan más allá de las micromotivaciones, pero, tal como señalan algunos autores y comprobamos en nuestro estudio, este planteamiento debe tener en cuenta la presencia de otros impulsos o mediaciones. Es decir, «no sólo se trata de que diferentes formas de acción colectiva se sostengan mediante motivaciones diferentes, sino que, además, un caso dado de acción colectiva contará también en la mayoría de los casos con participantes que estén motivados por preocupaciones distintas» (Elster, 1991: 68)

El contraste y la comparación del comportamiento de los voluntarios de nuestro estudio con algunos modelos de la acción colectiva nos descubren la pluralidad de motivos que justifican este tipo de conducta; revelan, asimismo, la multiplicidad de facetas que presenta el voluntariado y la diversidad de perspectivas desde las que se puede entender su actividad. Siguiendo estas premisas y atendiendo a los aspectos recogidos en nuestra investigación, damos un paso más y nos planteamos una última consideración sobre la naturaleza, la configuración y la expresión de su comportamiento, tratando con todo ello de adelantar una explicación general de estas iniciativas e intentando, al mismo tiempo, sugerir un modelo de análisis desde el que abordar su estudio y comprensión.

\subsection{LA ACCIÓN VOLUNTARIA: AMBIGÜEDADES Y PARADOJAS}

$\mathrm{Al}$ retomar las diferentes dimensiones que caracterizan a los voluntarios de Cruz Roja constatamos que su compromiso solidario y lo que éste implica se explica desde dos frentes distintos pero interrelacionados. Tiene su origen y se basa, por un lado, en la cooperación libremente asumida de individuos que deciden hacerse voluntarios atendiendo a sus expectativas y preocupaciones personales. Pero se plantea, por otro lado, en un contexto social que les trasciende. Su decisión, sus representaciones y actitudes están mediatizadas por la situación laboral, por los estudios realizados, por sus vínculos familiares y de 
amistad, por creencias y normas sociales. Su acción se dirige, además, a cubrir necesidades sociales y se plantea desde una organización que canaliza y orienta sus esfuerzos e intereses. Existe, por tanto, un ámbito subjetivo, personal, en el que radica y del que parte la decisión de hacerse voluntarios, pero encontramos también un contexto social del que depende y en el que se sitúa dicha opción.

Estos frentes pueden desglosarse, no obstante, en diferentes planos, cada uno de los cuales define el contenido y el sentido de la acción voluntaria. Nos encontramos, en primer lugar, ante una acción protagonizada por individuos que actúan a partir de sus preferencias y normas; que construyen imágenes y representaciones desde sus intereses y preocupaciones; que definen y eligen la organización desde la que cooperan, las personas a las que desean ayudar y las condiciones en las que desean ejercer su actividad.

El horizonte de esa acción no termina, sin embargo, en los propios sujetos, sino que supone la interacción con otros individuos. Las motivaciones, las representaciones que guían a los voluntarios se hallan subsumidas por las necesidades y urgencias de las personas a las que atienden. La opción personal implica o supone la atención a las necesidades y a los problemas de otros individuos; queda, en consecuencia, limitada por las personas a las que se dirige y por las mediaciones que éstas les imponen.

Se trata, asimismo, de una acción que se realiza desde una organización en la que se articulan los intereses y las expectativas personales con los intereses y urgencias de las personas a las que se atiende. La organización en la que colaboran los voluntarios constituye por ello un espacio social en el que se satisfacen sus propias urgencias y expectativas, así como las necesidades y carencias de las personas a las que pretenden ayudar.

Pero la existencia de estos tres planos conlleva o implica, además, un marco social más amplio en el que se plantean las necesidades y demandas, se generan las expectativas, se impulsan y mantienen las organizaciones de ayuda y se crean y reproducen las exigencias de reciprocidad y el sentido del deber.

Estos planos no existen, sin embargo, separados, sino que se dan en estrecha interconexión recíproca y se plantean en tensión. Observamos que los voluntarios y las personas a las que atienden participan de diferentes necesidades, se mueven por intereses diversos, pero unos y otros se aproximan y conectan desde sus propias carencias y desde sus respectivas preocupaciones. Por otro lado, su interrelación se produce en un mismo espacio y contexto social. Tanto los voluntarios como las personas a las que ayudan satisfacen sus expectativas a través de una organización que les aporta los medios y los instrumentos para cubrir sus diferentes necesidades. La organización existe por y para los voluntarios y para las personas a las que éstos atienden. Es, asimismo, la sociedad la que impulsa, favorece y mantiene las organizaciones de voluntariado y el sentido de la solidaridad, al mismo tiempo que genera las necesidades, los problemas y las carencias de los voluntarios y de las personas a las que éstos atienden. 
Todo ello nos descubre la ambivalencia y las paradojas que se hacen presentes en los voluntarios, en la organización desde la que cooperan y en la sociedad en la que se mueven. Tanto si nos centramos en los actores como si nos fijamos en el ámbito en el que surge y se proyecta su compromiso, se constata la existencia de una doble tensión en torno a la cual se plantea y desarrolla la acción voluntaria.

En el primer caso, si atendemos a los actores, constatamos que los voluntarios deciden cooperar y entran en la organización tratando de atender y de cuidar a terceras personas, pero al hacerlo buscan satisfacer, al mismo tiempo, sus propias demandas o cumplir con sus exigencias. Pretenden cubrir vacíos y necesidades de individuos y colectivos que padecen problemas, pero indirecta o directamente tratan de paliar sus propias carencias y de atender a sus principios o creencias. Se mueven por necesidades e intereses propios y ajenos, actúan guiados por su afán de ayudar y, al mismo tiempo, por el deseo de satisfacer sus necesidades u obligaciones.

Si nos situamos en el horizonte en el que se plantea y realiza su acción comprobamos que se trata de una actividad ensalzada e impulsada por la sociedad, que cobra cada vez más importancia y pone de relieve la emergencia de una nueva solidaridad y la presencia de nuevos actores sociales con un nuevo talante. El voluntariado goza de prestigio, los voluntarios tienen un reconocimiento social, sus organizaciones son financiadas y apoyadas desde el Estado y por los propios ciudadanos. Pero esta realidad descubre su doble función o el doble soporte en el que se apoya su existencia y expansión. Las organizaciones de voluntariado y la propia actividad de los voluntarios se orientan, por un lado, a la solución de necesidades sociales, tratan de cubrir los problemas y los déficits generados por la sociedad en las personas a las que atienden y satisfacen también las necesidades que la misma sociedad produce en los voluntarios. Es decir, en ambos casos se dirigen a resolver necesidades «materiales» (obtener un trabajo, cuidados físicos, ocupar el tiempo libre...) y "postmateriales» (alcanzar un reconocimiento, desplazar la soledad, experimentar sensaciones y emociones, estrechar vínculos sociales...) presentes en los voluntarios y en las personas a las que éstos ayudan. Existen, por otro lado y al mismo tiempo, para suplir o cubrir los déficits de la protección pública y privada; intentan llegar a colectivos y a personas que no reciben la ayuda procedente de las instituciones de protección (familia, Estado) o la perciben de un modo insuficiente. Puede por ello mantenerse que la sociedad, sus instituciones, impulsan el voluntariado, lo incentivan y estimulan, pero lo hacen para dar respuesta o cubrir los vacíos que ella misma genera y las deficiencias que se plantean en sus instituciones de protección.

Así, pues, la acción voluntaria y las organizaciones de voluntariado se presentan como una meta y como una referencia para los individuos que reciben ayuda y para los sujetos que aportan esa ayuda, pero son igualmente un instrumento social que desempeña la función de paliar carencias y cubrir déficits sociales. Existen, en definitiva, como un recurso individual, pues a través de 
ella distintos sujetos encuentran remedio a sus problemas y necesidades, y como un recurso social, pues desde ellas se atienden y cubren los déficits y los límites de la propia sociedad.

Estas constantes muestran el trasfondo, las tensiones que subyacen a los voluntarios; permiten captar, igualmente, las distintas dimensiones que intervienen en su existencia y que deben considerarse en su análisis y valoración. La comprensión y explicación del voluntariado exigen moverse en una pluralidad de horizontes, obligan a tener en cuenta distintos referentes: el horizonte «micro» y «macrosocial», la sociedad y los individuos, los resultados y el proceso, las necesidades y los valores, las emociones y la racionalidad, las decisiones personales y las presiones sociales, los actores y la organización desde la que actúan.

Todas estas dimensiones se articulan y conectan en un proceso de contradicciones y ambivalencias que descubren, al mismo tiempo, las ambigüedades y las paradojas de la sociedad en la que surgen y se expanden los nuevos voluntarios.

\section{BIBLIOGRAFÍA}

AlONSO, L. E. (1996): "Nuevos movimientos sociales y asociacionismo», en Las entidades voluntarias en España, Madrid, Ministerio de Asuntos Sociales, pp. 101-120.

Ascoli, U. (1987): "Estado de Bienestar y acción voluntaria», en REIS, 38: 119-162.

Barcellona, P. (1992): Postmodernidad y comunidad, Madrid, Trotta.

BÉJAR, E. (1988): El ámbito intimo. Privacidad, individualismo y modernidad, Madrid, Alianza.

BERnARdo, F., y RENES, V. (1986): "Voluntariado", en Materiales para un Glosario sobre Bienestar Social, Madrid, Cáritas-CEBS.

Bourdieu, P. (1988): Cosas dichas, Buenos Aires, Gedisa.

CAllejo, J., e IzQUIETA, J. L. (1996): Los nuevos voluntarios: entre el individualismo y la solidaridad, Valladolid, Diputación Provincial.

CASADO, D. (1992): Organizaciones voluntarias en España, Barcelona, Hacer.

CECS (1999): Informe España 1998. Una interpretación de su realidad social, Madrid, Encuentro.

CUCÓ, J.: "Vida asociativa», en M. GARCÍA FERRANDO, La sociedad valenciana de los noventa, Valencia, Alfons el Magnànim, pp. 241-286.

Dalton, J., y Kuechler, M. (eds.) (1992): Los nuevos movimientos sociales, Valencia, Alfons el Magnànim.

Demoscopia (1994): Estudio sobre los voluntarios de la Cruz Roja, Madrid, Cruz Roja.

Donati, P. (1997): «El desarrollo de las organizaciones del Tercer Sector en el proceso de modernización", en REIS, 79: 113-141.

EDIS (1987): Actitudes de la población ante las instituciones humanitarias de Cruz Roja, Madrid, Cruz Roja.

ELSTER, J. (1990): El cemento de la sociedad, Barcelona, Gedisa.

- (1991): "Racionalidad, moralidad y acción colectiva», en F. Aguiar (coord.), Intereses individuales y acción colectiva, Madrid, Pablo Iglesias, pp. 43-69.

- (1997): Egonomics, Barcelona, Gedisa.

FOESSA (1966): Madrid, Euroamérica.

FUNES, M. ${ }^{a}$ J. (1993): «Las organizaciones voluntarias en el proceso de construcción de la Sociedad Civil», en Sistema, 117: 55-70.

- (1995): La ilusión solidaria, Madrid, UNED. 
García Roca, J. (1994): Solidaridad y voluntariado, Santander, Sal Terrae.

GeErgen, K. G. (1992): El yo saturado, Barcelona, Paidós.

GEERTZ, C. (1987): La interpretación de las culturas, Barcelona, Gedisa.

Giddens, A. (1995): La constitución de la sociedad, Buenos Aires, Amorrortu.

Giner, S. (1995): «Lo privado público: altruismo y politeya democrática», en Estudios Políticos, 88: $9-27$

Giner, S., y Sarasa, S. (1996): Altruismo cívico y político-social, Barcelona, CSIC.

HiRshMAN, A. (1986): Interés privado y acción pública, México, FCE.

IZQUIETA, J. L. (1987): «Altruismo y solidaridad. Apuntes antropológicos», en Estudios Filosófi$\cos$, XXXVI: 439-478.

- (1998): «La Cultura», en Manual de Sociología, Valladolid, Universidad de Valladolid, pp. 133-156.

JAMES, S. (1989): The nonprofit sector in International Perspective, New York, Oxford University Press.

Kendrik, J., y Richard, J. R. (1991): «Meaning and Participation: Perspectives of Peace Movement Participants», en Research in Social Movements, Conflicts and Change, 13: 91-111.

KNOKE, D. (1990): Organizing for Collective Action, New York, Aldine de Gruyter.

LipOVETSKI, G. (1986): La era del vacio. Ensayo sobre el individualismo contemporáneo, Barcelona, Anagrama.

- (1994): El crepúsculo del deber. La ética indolora de los nuevos tiempos democráticos, Barcelona, Anagrama.

MANGHI, S. (1995): «Altruismo», en Ressegna Italiana de Sociologia, XXXVI: 433-459.

MCADAM, D. (1986): «Recruitment to high-risk activism: the case of Freedom Summer», en American Journal of Sociology, 92: 64-90.

MeIster, A. (1974): La participation dans les associations, París, Ouvrieres.

Melucci, A. (1989): Nomads of the Present, Philadelphia, Temple University Press.

OfFe, C. (1992): Partidos politicos y nuevos movimientos sociales, Madrid, Sistema.

Olson, M. (1992): La lógica de la acción colectiva (Los bienes públicos y la teoría de los grupos), México, Limusa.

PARsons, T. (1970): Apuntes sobre la teoría de la acción, Buenos Aires, Amorrortu.

Pizzorno, A. (1989): "Algún otro tipo de alteridad: una crítica a las teorías de la elección racional», en Sistema, 88: 27-42.

Prieto LaCACI, R. (1994): "Asociaciones voluntarias», en S. DEL CAMPO, Tendencias sociales en España 1960-1990, Bilbao, Fundación Bilbao-Vizcaya, pp. 197-217.

- (1999): Tendencias del asociacionismo juvenil en los años 90, Madrid, Ministerio de Trabajo y Asuntos Sociales.

Rodríguez Cabrero, G. (1996): «Las entidades voluntarias en la construcción del Bienestar Social», en Las Entidades voluntarias en España, Madrid, Ministerio de Asuntos Sociales, pp. 17-33.

RodríGUEZ IbÁNEZZ, J. E. (1995): «Entre el “postconvencionalismo” transnacional y el "neotradicionalismo" integrista: las sinuosidades de la identidad social tardomoderna", en Sistema, 125: 55-56.

SARASA, S. (1995): «La sociedad civil en la Europa del Sur. Una perspectiva comparada de las relaciones entre Estado y asociaciones altruistas», en El Estado de Bienestar en la Europa del Sur, Madrid, CSIC, pp. 157-186.

SCITOVsKi, T. (1988): Frustraciones de la riqueza. La satisfacción humana y la insatisfacción del consumidor, México, FCE.

SNOw, D.; ZurCher, L. A., y EKLAND-Olson, S. (1980): "Social networks and social movements: a microstructural approach to differential recruitment», en American Sociological Review, 45: 787-801.

SzTOMPKA, P. (1998): «Las lecciones de 1989 para la teoría sociológica», en Zona Abierta, 82/83: 143-163.

Tocqueville, A. De (1985): La democracia en América, Madrid, Alianza. 
TomaI, B. (comp.) (1991): Assoziazonismo, volontariato e nuova cittadinanza sociale, Milán, CENS.

TOURAINe, A. (1990): Los nuevos movimientos sociales hoy, Barcelona, Hacer.

- (1984): Le retour de l'acteur, París, Fayard.

Wuthnow, R. (1996): Actos de compasión. Cuidar de los demás y ayudarse a uno mismo, Madrid, Alianza.

\begin{abstract}
The growth and increasing prominence of altruistic voluntary work and the lack of empirical studies on the conduct and performances of these actors led us to study the voluntary workers of a representative organisation (Red Cross) with the aim of identifying the images, expectations and attitudes which inspire and guide them. This paper focuses on three aspects. It begins by defining and explaining the social context of the object of the study, and the theoretical perspective it is tackled from. It then goes on to identify and define the way voluntary workers perceive their commitment, the people they look after and the work they do, proposing a typology of the new volunteers. Finally, an analysis is made which, in addition to comparing this work with other studies and with models of collective action, contains one interpretation of the nature, meaning and social scope of voluntary work.
\end{abstract}


NOTAS DE INVESTIGACIÓN 